\title{
1. Development of transnational legal norms
}

In recent years, a rich body of work examining how 'legal norms are developed, conveyed and settled transnationally' has emerged, 'integrating both bottom-up and top-down analyses'. ${ }^{1}$ This growing body of work on 'transnational legal ordering' 2 is significant given the importance of engaging a wider cross-section of public and private actors in the development of legal norms beyond the nation state. ${ }^{3}$

It has been recognised that participation in global norm-making has not, in many cases, been representative of the diversity of global actors, with historically limited representation by non-western states. A 2020 survey of more than one million people conducted by the United Nations on the occasion of its 75th anniversary found that among the top priorities highlighted by global survey respondents was the need for expanded grass-roots engagement on the part of global institutions. This book addresses this gap by systematically analysing the role of the United Nations Commission on International Trade Law Regional Centre for Asia and the Pacific (UNCITRAL RCAP), established in 2012, in coordinating with private and public sector institutions in the Asia-Pacific on the development, interpretation and application of global cross-border dispute settlement guidelines. Since the mid-1950s, UNCITRAL has engaged in a process of global model law drafting, including in areas related to cross-border dispute resolution and trade. While such guidelines

1 Halliday, T.C., \& Carruthers, B.G. (2007). 'The Recursivity of Law: Global Norm Making and National Lawmaking in the Globalization of Corporate Insolvency Regimes.' American Journal of Sociology, 112(4), 1135-1202; Block-Lieb, S. and Halliday, T.C., Global Lawmakers: International Organizations in the Crafting of World Markets. Cambridge: Cambridge University Press, 2017, p. 456.

2 Halliday, T.C., \& Shaffer, G. (Eds). (2015). Transnational Legal Orders. Cambridge: Cambridge University Press; Lee, J.S. (2017). 'A Transnational Legal Process Perspective on Norm Making in International Arbitration,' Thesis presented to Seoul National University School of International Law.

3 Twining, W. (2000). Globalisation and Legal Theory. London: Butterworths; Tamanaha, B.Z. (2000). 'A Non-Essentialist Version of Legal Pluralism.' Journal of Law and Society, 27(2), 296-321; Zumbansen, P. (2010). 'Transnational Legal Pluralism.' Transnational Legal Theory, 1(2), 141-89; Halliday, T.C., \& Shaffer, G. (Eds.). (2015). Transnational Legal Orders. Cambridge: Cambridge University Press. 
provide for regional adaptation, a growing body of work is advocating for expanded representation in global law-making at both the vertical (between global institutions and individual citizens) and horizontal (between states and international organisations) levels, ${ }^{4}$ with the aim of strengthening legitimacy through more effective participation, ${ }^{5}$ external warrants, ${ }^{6}$ regional adaptation ${ }^{7}$ and cross-sectional representation. ${ }^{8}$ In response to such observations, this book aims to distil positive lessons learned from 'decentralised transnational law engagement', to elucidate regional dynamics and to glean best practices in the form of law and policy recommendations.

Recent research highlights the importance of overcoming representational deficits in global law-making at both the vertical and horizontal levels, ${ }^{9}$ while growing interdependence requires coordination among and input from a diversity of actors. ${ }^{10}$

In recognition of the need to directly engage with regional legal communities, the UNCITRAL Regional Centre for the Asia Pacific (RCAP) was established in Incheon, Korea in January 2012, as UNCITRAL's first regional centre in the Asia-Pacific region. As the 'first one of its kind' and representing 'a novel yet important step for UNCITRAL', its main objectives have been to 'engage in coordination activities with international and regional organizations and ... function as a channel of communication between States in the region and UNCITRAL'. ${ }^{11}$

In contributing to the formation of transnational soft law, UNCITRAL comprises numerous member states created by the UN General Assembly.

4 Alvarez, J. (2007). 'Introducing the Themes [International Law and Democratic Theory].' Victoria University of Wellington Law Review, 38, 159-63.

5 Alvarez, J. (2007). 'Introducing the Themes [International Law and Democratic Theory].' Victoria University of Wellington Law Review, 38, 159-63.

6 Halliday, T.C., \& Carruthers, B.G. (2007). 'The Recursivity of Law: Global Norm Making and National Lawmaking in the Globalization of Corporate Insolvency Regimes.' American Journal of Sociology, 112(4), 1135-1202.

7 Ali, S. (2011). Resolving Disputes in the Asia-Pacific: International Mediation and Arbitration in East Asia and the West. Abingdon: Routledge.

8 Wheatley, S. (2010). The Democratic Legitimacy of International Law. London: Bloomsbury Publishing.

9 Alvarez, J. (2007). 'Introducing the Themes [International Law and Democratic Theory].' Victoria University of Wellington Law Review, 38, 159-63.

10 Wheatley, S. (2010). The Democratic Legitimacy of International Law. London: Bloomsbury Publishing; Brooks, R.R.W., 'Supermodular Architecture of Inclusion', 30 Harv. J.L. \& Gender 379 (2007) (with Valerie Purdie-Vaughns).

${ }_{11}$ UNCITRAL. (2011). Enhancing International Trade and Development in the Asia-Pacific Region UNCITRAL Regional Centre for Asia and the Pacific-Opening speech by Ms. Patricia O'Brien. Retrieved from http://legal.un.org/ola/media/info _from_lc/POB\%20Incheon-Welcome\%20Address.pdf. 
Membership is oriented towards representation of a variety of legal traditions and economic conditions.

The establishment of the UNCITRAL RCAP reflects the emerging development of an increasingly decentralised transnational legal order. This may be seen partly as a response to an attempt to address the challenges of engaging with a diversity of legal systems and structures. Variation in the degree of concentration or fragmentation of central state institutions has posed challenges for recursivity, requiring decentralised approaches such as engaging directly with civil society, markets, judges and/or lawyers to reduce transaction costs ${ }^{12}$ in global regulation, ${ }^{13}$ while recognising the state as central to advancing normative and instrumental aims. ${ }^{14}$

The mandate of the centre is to enhance international trade and development in the Asia-Pacific region. In particular, it is charged with the mandate of promoting the principle of the rule of law ${ }^{15}$ by providing internationally acceptable rules in the field of commercial law and supporting the enactment of such rules. ${ }^{16}$ Broadly speaking, the role of RCAP can thus be understood as facilitating the development of international trade law from the bottom up, complementing and supporting the legislative activities of UNCITRAL and its Working Groups.

Reflecting characteristics of a decentralised transnational legal ordering (TLO), RCAP provides an avenue for two-way communication at the regional level. It not only channels information from UNCITRAL to public and private entities in the Asia-Pacific, but also enables the collection of feedback and regional learning for further legislative work by UNCITRAL.

As several years have passed since UNCITRAL RCAP's inception in 2012, and given the ongoing refinement, adaptation and interpretation of model laws on cross-border dispute settlement, now is an opportune time to examine whether, and if so how, regional centres can contribute to overcoming rep-

12 See Hadfield, G.K. (2001) 'Privatizing Commercial Law.' Regulation, 24(1), 40-5; and Hadfield, G.K. (2009) 'The Public and the Private in the Provision of Law for Global Transactions' in Contractual Certainty in International Trade: Empirical Studies and Theoretical Debates on Instituitional Support for Global Economic Exchanges, edited by Volkmar Gessner, Oxford Publishing House, 239-56.

13 See Teubner, G. (2015). 'Transnational Economic Constitutionalism in the Varieties of Capitalism.' Italian Law Journal, 1(2), 219-248.

${ }_{14}$ Halliday, T.C., \& Shaffer, G. (Eds). (2015). Transnational Legal Orders. Cambridge: Cambridge University Press, 18.

15 For discussion on renewed respect for the rule of law in East Asia, see: Miyazawa, S., Ji, W., Fukurai, H., Chan, K.W., and Vanhullebusch, M. eds., East Asia's Renewed Respect for the Rule of Law in the 21 ${ }^{\text {st }}$ Century: The Future of Legal and Judicial Landscapes in East Asia (Leiden: Brill/Nijhoff, 2015) pp. 343.

16 See www.uncitral.org/uncitral/en/tac/rcap.html 
resentational deficits in soft law formation. Such examination is particularly timely given that 'several other proposals to establish regional centres in other parts of the world are under consideration, with some focusing on specific sub-regions'. ${ }^{17}$

While soft law in general is the subject of a significant body of scholarship, the contributions of Asia-Pacific nations in the formation, development and application of instruments regulating cross-border dispute resolution remain understudied, despite the rapidly expanding caseloads of regional arbitral institutions. In the Asia-Pacific region, soft law instruments, including the Model Law on International Commercial Arbitration, are increasingly being incorporated into regional arbitration laws. At the same time, domestic interpretations and applications of such laws offer fresh insights for future law revisions. Given the active role of Asia-Pacific states in the interpretation and application of global model laws and the development of new mechanisms for cross-border dispute settlement, understanding the interaction between regional engagement and global practice is timely.

\section{OVERVIEW OF THE BOOK AND RESEARCH METHODOLOGY}

This book is divided into three parts, each of which analyses whether, and if so how, decentralised engagement in soft law-making through UNCITRAL RCAP contributes to overcoming vertical and horizontal representational deficits in the global soft law-making process, and to testing the proposition that the presence of regional centres has the potential to expand participation in global soft law-making. It carries out a novel analysis of the influence of transnational engagement in overcoming representational deficits in the design of global soft law pertaining to cross-border dispute settlement. It does this by comparing the impact of two forms of engagement in the Asia-Pacific region - traditional 'centralised' engagement and the more recent 'decentralised' form - on the soft law-making process over a ten-year period. The former is characterised by formal intermittent participation in global deliberation processes at UN headquarters through Working Group II (dispute resolution) meetings prior to 2012, and the latter by informal, localised and decentralised engagement facilitated through the regional centre after January 2012 when the UNCITRAL RCAP was established.

17 UNCITRAL. (2011). Enhancing International Trade and Development in the Asia-Pacific Region UNCITRAL Regional Centre for Asia and the Pacific-Opening speech by Ms. Patricia O'Brien. Retrieved from http://legal.un.org/ola/media/info from_lc/POB\%20Incheon-Welcome\%20Address.pdf. 
In examining whether, and if so how, decentralised engagement in soft law-making through UNCITRAL RCAP contributes to overcoming vertical and horizontal representational deficits in the global soft law-making process, the research methodology relies on a triangulating approach consisting of an inductive review of secondary sources, analysis of Working Group II and III participation logs, post-2012 enactment status of UNCITRAL international arbitration and conciliation texts in the Asia-Pacific region and selective surveys of private non-state actors, including arbitral institutions, organisations and legal professionals in the region.

The Asia-Pacific region is defined in this book according to UNCITRAL, as consisting of 56 states, from Lebanon to the South Pacific islands, excluding Russia, Caucasus and Israel; ${ }^{18}$ for the purposes of this study it also includes Australia and New Zealand.

Following an introduction outlining the theoretical and practical challenges of extending representation in transnational soft law norm formation, Part I of the book explores the origins of RCAP. In evaluating the role of RCAP in soft law development in the Asia-Pacific region, Part I also introduces a novel set of indicators tracking participation, representation and diversity in the global law-making process. Among the indicators developed and applied in this study include measures tracking Asia-Pacific contributions to UNCITRAL Working Group II and III; frequency of input and participation during working group sessions; state-level participation in Working Group II and III sessions; Regional Observer participation in Working Group II and III; regional judicial interpretations of the UNCITRAL Model Law; participation in UNCITRAL-sponsored activities relating to dispute resolution reform; adoption of UNCITRAL instruments following the opening of RCAP; and regional opportunities for input into UNCITRAL reform efforts.

This new set of indicators is used in the book to track the UNCITRAL Regional Centre for the Asia-Pacific's progress in enhancing inclusiveness and diversity, and therefore legitimacy, in the soft law-making process. They draw from existing governance literature encouraging the evaluation of openness and broad engagement. ${ }^{19}$ Future indicators that may be added to this list include those focusing on whether resolutions and outcomes are arrived at after

See www.un.org/depts/DGACM/RegionalGroups.shtml

19 Alvarez, J. (2007). 'Introducing the Themes.' Victoria University of Wellington Law Review, 38(159), 159-74. 
reasoned deliberations ${ }^{20}$ and indicators evaluating whether there is acceptance of the possibility of error by the relevant global regulatory institutions. ${ }^{21}$

Part II explores RCAP case studies in extending regional engagement in UNCITRAL model instruments. These case studies include an exploration of how Asia-Pacific participation has expanded during consultations and implementation of the Model Law on Arbitration, the Conciliation Rules, the Singapore Convention on Cross Border Enforcement of Mediated Settlements, the Investor-State Arbitration Rules, and transparency and online dispute resolution rules. This horizontal representation analysis is focused specifically on the post-2012 contributions of Asia-Pacific states in the context of UNCITRAL Working Group II (dispute resolution) meetings and the implementation of legislation based on the Model Law text. It tracks the extent to which 'external warrants of legitimacy', ${ }^{22}$ including the breadth of consultation in script formation, are fulfilled in practice through textual analysis of working group meeting notes.

Part III then examines empirical findings on the contribution of RCAP in extending regional representation through examination of survey data, working group participation statistics and substantive contributions to global law-making by legislative innovations developed in Asia-Pacific states. To examine vertical representation, court decisions from the Asia-Pacific states implementing and interpreting the Model Law text on international arbitration are collected from the UNCITRAL case law collection system (CLOUT) to determine states' specific contributions to the interpretation and application of UNCITRAL texts in the Asia-Pacific region, and the extent to which regional legislation influences the further reform of global model laws.

A survey of legal and dispute resolution practitioners involved in the implementation and interpretation of UNCITRAL model laws is presented in this part. A small-N purposive sample of 50 practitioners involved in UNCITRAL Working Group II (dispute resolution) deliberations is analysed. While the results are not generalisable, the survey complements working group participation logs and case analysis by providing insights into practitioners' perceptions of the impact of UNCITRAL RCAP on the development, interpretation and implementation of the Model Law text in state practice and the contribution of regional expertise to informing the global refinement of that text.

20 Wheatley, S. (2010). The Democratic Legitimacy of International Law. Oxford: Hart Publishing, 87.

${ }_{21}$ Wheatley, S. (2010). The Democratic Legitimacy of International Law. Oxford: Hart Publishing, 319.

${ }_{22}$ Halliday, T.C., \& Carruthers, B.G. (2007). 'The Recursivity of Law: Global Norm Making and National Lawmaking in the Globalization of Corporate Insolvency Regimes.' American Journal of Sociology, 112(4), 1135-1202. 
Finally, the book concludes with lessons learned, policy recommendations and illustrative indicators encouraging inclusive approaches to regional representation in global soft law-making.

\section{KEY FINDINGS}

The book's key findings, drawing on in-depth case studies, a survey and quantitative analysis of UNCITRAL working group participation logs, suggest that the emergence of regional centres such as the UNCITRAL Regional Centre for the Asia-Pacific, while still in their infancy, have corresponded with the emergence of a new form of 'decentralised transnational legal ordering' associated with growing regional engagement and participation in global soft law design. This is evidenced by a 63 per cent increase in the frequency of Asia-Pacific regional input in WG II meetings, an 8 per cent increase in official Asia-Pacific representation in the WG II, a 6.2 per cent increase in the number of observers from the Asia-Pacific region, and an average increase of 32 per cent in perceived levels of engagement and participation among regional stakeholders over a seven-year period. Specifically, survey respondents reported an increase of 34 per cent in the 'presence of mechanisms allowing a wide range of voices to be heard', an increase of 35 per cent in 'pro-active engagement with relevant stakeholders', an increase of 25 per cent in perceived 'participation of delegations in the sessions of Working Group II', and an increase of 34 per cent in 'understanding of UNCITRAL instruments amongst diverse stakeholders for enactment of legislation based on the Model Law' since the establishment of RCAP in 2012.

For each of UNCITRAL's dispute resolution instruments, following the opening of the Regional Centre, increased adoption trends in the region are also evident. This has included an increase of 100 per cent in adoption of the Conciliation Rules and an increase of 38 per cent in adoption of the Model Law. To date, 21 regions in the Asia-Pacific are among a total of 53 states globally to have adopted the Singapore Convention on International Settlement Agreements Resulting from Mediation.

Such findings suggest the emergence of a new form of 'decentralised transnational legal ordering' associated with growing regional engagement in global soft law design.

Pre-2012 UNCITRAL may be described as a 'centralised' transnational legal order. Prior to 2012, all working group and intersession meetings took place in either New York or Vienna. After 2012, with the establishment of the Regional Centre for Asia and the Pacific, the UNCITRAL system transitioned to what may be described as a 'decentralized TLO', with the first intersession meetings taking place in Korea, followed by meetings in Latin America. 
Prior to 2012, local engagement with UNCITRAL's centralised TLO activity was limited. For example, the absence of regional intersession meetings meant there were few spaces for non-state actors to engage in model law construction. After 2012, with the introduction of regional spaces, the quality and richness of exchange was enhanced through numerous local conferences, workshops and events.

It is suggested here that in both centralised and decentralised TLO systems, states continue to play a significant role in transnational law-making. However, the extent and depth of engagement varies. As TLOs become more decentralised, the depth and quality of access and engagement in law-making activities deepens. Since the inception of UNCITRAL, states have been central to the drafting of its Model Laws and to revision of national laws to incorporate such models. ${ }^{23}$

While states play an important role in both centralised and decentralised TLOs, private parties are also central to the emergence and operation of the transnational system. ${ }^{24}$ Yet within the context of the pre-2012 UNCITRAL TLO, it was largely western non-governmental organisations that had access to meeting venues in New York and Vienna.

With the introduction of RCAP, an increasingly decentralised TLO has emerged. This may be seen partly as a response to an attempt to address the challenges of engaging effectively with a diversity of legal systems and structures and engaging directly with civil society, markets, judges and/or lawyers so as to reduce transaction $\operatorname{costs}^{25}$ in global regulation ${ }^{26}$ while recognising the state as central to advancing normative and instrumental aims. ${ }^{27}$

This book finds that the direction of decentralised transnational engagement is mutual - it moves both from the global to the regional and vice versa. In addition to regional adaptations of UNCITRAL text, nearly a quarter of respondents, or 24 per cent, believed that unique approaches to the interpretation and implementation of the UNCITRAL model instruments in the

23 Halliday, T.C., \& Shaffer, G. (Eds). (2015). Transnational Legal Orders. Cambridge: Cambridge University Press, 5.

${ }^{24}$ Halliday, T.C., \& Shaffer, G. (Eds). (2015). Transnational Legal Orders. Cambridge: Cambridge University Press, 6.

25 See Hadfield, G.K. (2001) 'Privatizing Commercial Law.' Regulation, 24(1), 40-5; and Hadfield, G.K. (2009) 'The Public and the Private in the Provision of Law for Global Transactions' in Contractual Certainty in International Trade: Empirical Studies and Theoretical Debates on Institutional Support for Global Economic Exchanges, edited by Volkmar Gessner, Oxford Publishing House, 239-56.

26 See Teubner, G. (2015). 'Transnational Economic Constitutionalism in the Varieties of Capitalism.' Italian Law Journal, 1(2), 219-48.

27 Halliday, T.C., \& Shaffer, G. (Eds). (2015). Transnational Legal Orders. Cambridge: Cambridge University Press, 18. 
Asia-Pacific have informed UNCITRAL developments in other regions and globally. Legal developments and innovations emerging from within the Asia-Pacific judiciary and arbitration sector, such as emergency arbitrator procedures and efficiency rules, have informed ongoing global innovation in soft law making. Inaugural localised and increasingly accessible intersession meetings have engaged a growing number of practitioners in conversations about soft law design.

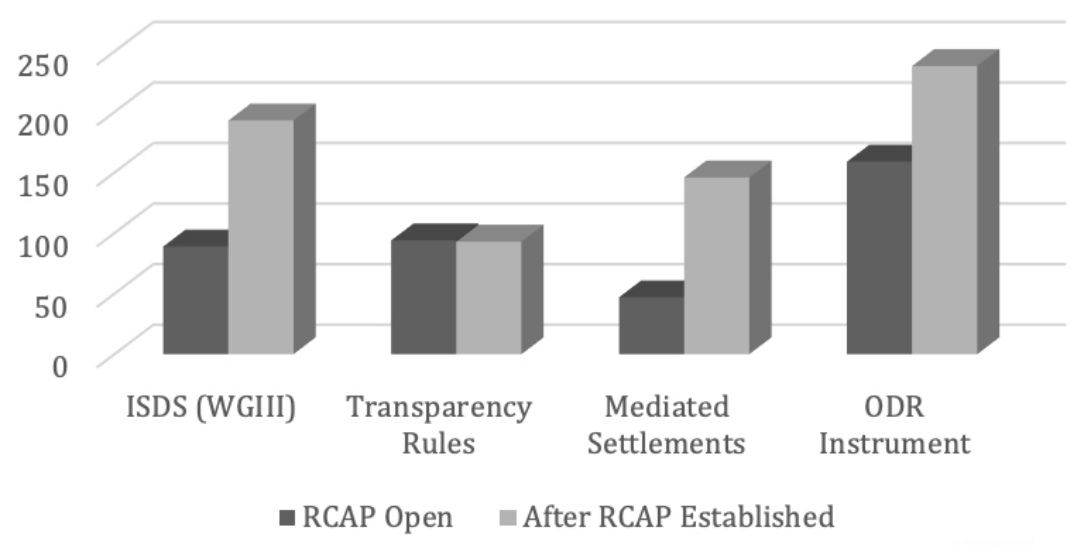

Figure 1.1 Asia-Pacific Participation after RCAP established as tracked through verbal contributions to WGII and III Consultations

UNCITRAL Working Group log analysis suggests that after the opening of RCAP in 2012, Asia-Pacific member state participation in UNCITRAL Working Group II and III consultations increased for the majority of all subject matter and in one instance remained stable (see Figure 1.1). The number of individual session contributions increased to 193 (WGIII, s38) from 89 (WGIII, s35) in discussions on the development of an investor-State dispute settlement instrument; it remained relatively stable at 93 (WGII, s60) from 94 (WGII, s59) in discussions on the UNCITRAL Rules on Transparency in Treaty-based investor-State Arbitration; and it increased to 146 (WGII, s65) from 47 (WGII, s61) and to 238 (WGIII, s32) from 159 (WGIII, s28) in discussions on the drafting of online dispute resolution rules. 
RCAP has made a direct contribution to the harmonisation and adoption of dispute resolution-related laws in the Asia-Pacific region. ${ }^{28}$ In 2012, 20 out of 56 States and territories in the region ( 35 per cent) had arbitration legislation based on the UNCITRAL Model Law on International Commercial Arbitration. Today, 36 States and territories in the region have adopted the Model Law (64 per cent), representing an increase of 29 per cent since the establishment of RCAP. Currently, RCAP is assisting several jurisdictions to enact updated arbitration laws. The Asia-Pacific region now accounts for 47 per cent of total States and 58 per cent of total jurisdictions adopting the Model Law. ${ }^{29}$

Since 2012 there have been four new accessions to the Convention on the Recognition and Enforcement of Foreign Arbitral Awards (New York, 1958), doubling the pace of regional accessions over the previous five years. Assistance is currently being provided by RCAP to several States in the South Pacific. $^{30}$

A large number of stakeholders have received technical assistance from RCAP since its opening, including more than 3000 judges, officials, practitioners and other others. These stakeholders have come from all over the Asia-Pacific region, including Afghanistan, Australia, Bahrain, Bangladesh, Bhutan, Brunei Darussalam, Cambodia, China (including the Special Administrative Regions of Hong Kong and Macau), Democratic People's Republic of Korea, Fiji, India, Iran, Japan, Kazakhstan, Lao PDR, Malaysia, Maldives, Mongolia, Myanmar, Nepal, Papua New Guinea, the Philippines, Qatar, Republic of Korea, Pakistan, Palau, Samoa, Singapore, Solomon Islands, Sri Lanka, TimorLeste, Thailand, Turkmenistan and Vietnam. ${ }^{31}$

Since its inception, RCAP has made a number of contributions to regional legal development in the Asia-Pacific. Each of the above efforts demonstrates the functions of a decentralised TLO in practice.

These findings provide useful insights encouraging the development of decentralised transnational legal engagement in regions with historically limited representation in global law-making, including within Africa, the Middle East and South America.

28 Email by Joāo Ribeiro-Bidaoui, Former UNCITRAL Regional Head for Asia and the Pacific, UNCITRAL in Incheon, Republic of Korea.

29 Email by Joāo Ribeiro-Bidaoui, Former UNCITRAL Regional Head for Asia and the Pacific, UNCITRAL in Incheon, Republic of Korea.

30 Email by Joāo Ribeiro-Bidaoui, Former UNCITRAL Regional Head for Asia and the Pacific, UNCITRAL in Incheon, Republic of Korea.

31 Email by Joāo Ribeiro-Bidaoui, Former UNCITRAL Regional Head for Asia and the Pacific, UNCITRAL in Incheon, Republic of Korea. 


\section{BACKGROUND OF RESEARCH}

In examining the question of whether there is any relationship between the establishment of regional soft law-coordinating institutions and advances in decentralised engagement within the Asia-Pacific region, this book engages with and contributes to two major strands of the theoretical literature: (1) work analysing soft law formation in the context of globalisation and legal pluralism and (2) studies of legitimacy and representation in the formation of soft law. Both strands offer useful theoretical insights for framing the examination of decentralised engagement, and yet noticeably absent from existing analyses are investigations of the dynamics of participation by members of the Asia-Pacific arbitration community, alongside other global actors, in the formation of cross-border dispute settlement guidelines.

\section{SOFT LAW FORMATION IN THE CONTEXT OF LEGAL PLURALISM AND GLOBALISATION}

The literature examining the nature of soft law is rich. Traditionally, soft law has been regarded as a residual category constituting aspirational norms in contrast to hard law 'treaties'. ${ }^{32}$ Soft law exerts influence through its normative weight, reflected in model laws, instruments and codifications, creating internal and external pressure for compliance. ${ }^{33}$ Soft law pertaining to cross-border arbitration and dispute settlement in many cases straddles both private ${ }^{34}$ and

32 Lynch, O.J., \& Maggio, G. (1997). Human Rights, Environment and Economic Development: Existing and Emerging Standards in International Law and Global Society. Washington, DC: CIELP.

33 Lowe, V. (2007). International Law. Oxford: Oxford University Press, 95-6; Wheatley, S. (2010). The Democratic Legitimacy of International Law. London: Bloomsbury Publishing.

34 Kurkela, M., \& Turunen, S. (2010). Due Process in International Commercial Arbitration. New York: Oxford University Press; Drolshammer, J.I., \& Pfeifer, M. (Eds). (2001). The Internationalization of the Practice of Law. Dordrecht: Martinus Nijhoff Publishers; Ahdieh, R.B. (2007). 'From Federalism to Intersystemic Governance: The Changing Nature of Modern Jurisdiction.' Emory Law Journal, 57(1), 23-4; Mistelis, L., Kröll, S. \& Perales Viscasillas, M. (2011). UN Convention on Contracts for the International Sale of Goods (CISG): [commentary]. München: Oxford; Portland, OR: C.H. Beck; Hart Pub; Nottage, L. (2006). 'The Procedural Lex Mercatoria: The Past, Present and Future of International Commercial Arbitration.' Sydney Law School Research Paper No. 06/51 (No. 03/1E). CDAMS Discussion Paper; Drahos, P., \& Braithwaite, J. (2000). Global Business Regulation. Cambridge: Cambridge University Press. 
public law, ${ }^{35}$ in that some instruments, such as the United Nations Commission on International Trade Law (UNCITRAL) Model Law on International Commercial Arbitration ('Model Law' hereafter), influence the formation of state law, whereas other procedural rules and guidelines are often applied privately as a matter of contract. ${ }^{36}$ Absent an independent 'transnational arbitral regime', ${ }^{37}$ the aim of soft law is to fill the gaps in applicable arbitration rules ${ }^{38}$ through 'flexible legal instruments'. ${ }^{39}$ Common features of arbitral soft law include restatements of so-called best practice and complementing applicable arbitration rules by guiding parties and/or tribunals through non-binding principles, ${ }^{40}$ while exerting normative influence, ${ }^{41}$ given that perceptions of obliga-

35 Shaffer, G.C., \& Pollack, M.A. (2010). 'Hard vs. Soft Law: Alternatives, Complements, and Antagonists in International Governance.' Minnesota Law Review, 94, 706-99; Stipanowich, T.J. (2014). 'Soft Law in the Organization and General Conduct of Commercial Arbitration Proceedings' in Soft Law in International Arbitration, edited by L.W. Newman \& M.J. Radine (New York: JurisNet LLC), 73-98; Shelton, D. (2009). Human Rights and Environment: Past, Present and Future Linkages and the Value of a Declaration. High Level Experts Meeting on the New Future of Human Rights and the Environment: Moving the Global Agenda Forward, Nairobi, 30 Nov-1 Dec 2009, Background Paper - Draft; Handl, G.F. (1988). 'A Hard Look at Soft Law.' American Society International Law Proceedings, 82, 371-3; Chinkin, C.M. (1989). 'The Challenge of Soft Law: Development and Change in International Law.' The International and Comparative Law Quarterly, 38, 850-66; Flückiger, A. (2009). 'Why Do We Obey Soft Law?' in Rediscovering Public Law and Public Administration in Comparative Policy Analysis: A Tribute to Peter Knoepfel, edited by S. Nahrath \& F. Varone, Lausanne: PPUR Presses Polytechniques, 45-62; Mistelis, L. (2006). 'Reality Test: Current State of Affairs in Theory and Practice Relating to "Lex Arbitri".' American Review of International Arbitration, 17, 155-81.

36 Kaufmann-Kohler, G. (2010). 'Soft Law in International Arbitration: Codification and Normativity.' Journal of International Dispute Settlement, 1, 1-17.

37 Schultz, T. (2011). 'Secondary Rules of Recognition and Relative Legality in Transnational Regimes.' The American Journal of Jurisprudence, 56, 59-88; Lew, J.D.M. (2013). 'Is There a "Global Free-standing Body of Substantive Arbitration Law"?' in International Arbitration, The Coming of a New Age? edited by A. van den Berg, Alphen aan den Rijn: Kluwer Law International, 53-61.

38 Kurkela, M., \& Turunen, S. (2010). Due Process in International Commercial Arbitration. New York: Oxford University Press.

39 Zumbansen, P. (2002). 'Piercing the Legal Veil: Commercial Arbitration and Transnational Law.' European Law Journal, 8(3), 400-32.

40 Favalli, D. (2015). 'An Overview of Existing Para-regulatory Texts ("PRTs"): Analysis, Facts and Figures' in The Sense and Non-Sense of Guidelines, Rules and Other Para-Regulatory Texts in International Arbitration, ASA Special Series No. 37 , edited by D. Favalli, New York: JurisNet, LLC, 1-15.

${ }^{41}$ Lakhani, A. (2006). 'The Role of Citizens and the Future of International Law: A Paradigm for a Changing World.' Cardozo Journal of Conflict Resolution, 8, 159. 
tions $^{42}$ often influence practice ${ }^{43}$ for reasons of convenience, predictability or group membership. ${ }^{44}$

On the subject of soft law formation, the literature has examined how soft law 'regimes ... rely primarily on the participation and resources of nongovernmental actors in the construction, operation and implementation of ... governance arrangement $[\mathrm{s}]$ '. ${ }^{45}$ Emergent law develops through 'manifestations of transnational actors and their regulations'. ${ }^{46}$ The concept of international legal fields has been used to describe the symbolic terrain within which private arbitrators function within their own networks, hierarchical relationships and expertise. ${ }^{47}$ Soft law may be formed through the compilation of norms reflecting the current state of the law or through the more interventionist approach of 'codification as innovation' ${ }^{48}$ Private non-state actors, comprising arbitral institutions and organisations, legal professionals, and academia, ${ }^{49}$ play an important role in the development of international commercial arbitration as members of a global epistemic community. Their participation has been accelerated through processes of globalisation that facilitate social network formation and through the grouping of private actors into a global community ${ }^{50}$ which is in line with the notion of ubi societas, ibi regula, by which rules necessarily evolve within a particular community. ${ }^{51}$

42 Guzman, A.T., \& Meyer, T. L. (2010), 'International Soft Law.' Journal of Legal Analysis, 2, 171-225.

43 Kaufmann-Kohler, G. (2010). 'Soft Law in International Arbitration: Codification and Normativity.' Journal of International Dispute Settlement, 1, 1-17.

44 Flückiger, A. (2009). 'Why Do We Obey Soft Law?' in Rediscovering Public Law and Public Administration in Comparative Policy Analysis: A Tribute to Peter Knoepfel, edited by S. Nahrath \& F. Varone, Lausanne: PPUR Presses Polytechniques, $45-62$.

45 Kirton, J.J., \& Trebilcock, M.J. (2004). Hard Choices, Soft Law: Voluntary Standards in Global Trade, Environment and Social Governance. Aldershot, England; Burlington, VT: Ashgate, 12.

46 Zumbansen, P. (2002). 'Piercing the Legal Veil: Commercial Arbitration and Transnational Law.' European Law Journal, 8(3), 400-32.

47 Dezalay, Y., \& Garth, B.G. (1996). Dealing in Virtue: International Commercial Arbitration and the Construction of a Transnational Legal Order. Chicago: University of Chicago Press.

48 Kaufmann-Kohler, G. (2010). 'Soft Law in International Arbitration: Codification and Normativity.' Journal of International Dispute Settlement, 1, 1-17.

49 Lynch, K. (2003). The Forces of Economic Globalization: Challenges to the Regime of International Commercial Arbitration. The Hague: Kluwer Law International.

50 Kaufmann-Kohler, G. (2010). 'Soft Law in International Arbitration: Codification and Normativity.' Journal of International Dispute Settlement, 1, 1-17.

51 Schultz, T. (2011). 'Secondary Rules of Recognition and Relative Legality in Transnational Regimes.' The American Journal of Jurisprudence, 56, 59-88. 
Such analysis provides fruitful insight into the processes of soft law norm formation at the global level. At the same time, the dynamic and significant contributions of members of the Asia-Pacific arbitration community to the formation of guidelines on cross-border dispute settlement norms - the focus of this book - require further investigation.

In addition to the contributions of private actors and networks in soft law formation, scholars of legal pluralism have examined the diverse circumstances 'in which two or more legal systems coexist in the same social field', ${ }^{2}$ with implications for the interplay of soft law at the local, regional, national and global levels. ${ }^{53}$ Contributing to the normative and descriptive complexities of diverse legal systems interfacing transnationally, legal pluralism highlights the 'coexistence and interaction of different forms and sources of law within a more or less unified legal order' and acknowledges that national legislative and judicial orders are just two of a multiplicity of legal orders that regulate lives. ${ }^{54}$ Scholars have recently begun to address the nature of the interaction between globalisation, on the one hand, and the diversity of normative systems, on the other, in the field of international arbitration practice. ${ }^{55}$ This book extends such analysis to the role of regional centres in the Asia-Pacific and their contribution to decentralised engagement in global soft law formation.

\section{LEGITIMACY AND REPRESENTATION IN SOFT LAW FORMATION}

The second strand of literature with which this book engages is scholarship addressing the legitimacy of soft law-making institutions, particularly in the realm of dispute settlement. Although it has been suggested that soft law has

52 Moore, S.F. (1986). Social Facts and Fabrications: Customary Law on Kilimanjaro 1880-1980. Cambridge: Cambridge University Press; Merry, S.E. (1991). 'Law and Colonialism.' Law and Society Review, 25, 879-922; Tamanaha, B.Z. (2000). 'A Non-Essentialist Version of Legal Pluralism.' Journal of Law and Society, 27(2), 296-321.

53 Twining, W. (2000). Globalisation and Legal Theory. London: Butterworths; Teubner, G. (2012). Constitutional Fragments: Societal Constitutionalism and Globalization. Oxford: Oxford University Press; Zumbansen, P. (2010). 'Transnational Legal Pluralism.' Transnational Legal Theory, 1(2), 141-89; Berman, P.S. (2009). 'The New Legal Pluralism.' Annual Review of Law and Social Science, 5, 225-42; Cotterrell, R. (2008). 'Transnational Communities and the Concept of Law.' Ratio Juris, 21(1), 1-18.

54 Selznick, P. (1992). The Moral Commonwealth: Social Theory and the Promise of Community. Berkeley: University of California Press.

55 Ali, S. (2011). Resolving Disputes in the Asia-Pacific: International Mediation and Arbitration in East Asia and the West. Abingdon: Routledge. 
become nearly indispensable in international arbitral practice, ${ }^{56}$ questions regarding its representativeness remain open, due in part to the observation that 'the capacity of law to deliver justice depends on the range of interests it recognizes and protects'. ${ }^{57}$

The emergence of soft law in international arbitration has led to increased predictability, yet the challenges related to issues of legitimacy, consistent application and representation have yet to be sufficiently resolved. ${ }^{58}$ Reform by way of amendments to existing soft law or the proper drafting of new instruments has been advocated. This book examines how regional centres contribute to the drafting of such instruments through engagement with regional actors and institutions.

With respect to the question of legitimacy of soft law instruments, traditional principles of governance suggest that consent is built upon the notion of equality and the common will of members of society. ${ }^{59}$ This is consistent with the understanding that those who are subject to a set of rules should have a say in their creation. ${ }^{60}$ At the same time, in some cases, when full input is not possible, reference to best practice from a global range of experiences ${ }^{61}$ is preferable to the alternative of violating due process. ${ }^{62}$ Warrants of representativeness may be based on the breadth of consultation in creating the script; the quality of the exercise involved in script formulation; the scope of organisational or institutional cooperation; the empirical bases from which norms are developed; and the kinds of forums in which norms have been presented and

56 Reismann, W.M. (1988). 'A Hard Look at Soft Law.' Yale Law School Faculty Scholarship Series, Paper 750 (http://digitalcommons.law.yale.edu/fss_papers/750), 373-7.

57 Selznick, P. (1992). The Moral Commonwealth: Social Theory and the Promise of Community. Berkeley: University of California Press.

58 Menkel-Meadow, C. (2011). 'Why and How to Study "Transnational” Law.' UC Irvine Law Review, 1(1), 97.

59 Kant, I. (1970 [1793]). 'On the Common Saying: This May be True in Theory, but it Does Not Apply in Practice' in Kant's Political Writings, edited by Hans Reiss, Cambridge: Cambridge University Press, 77.

60 Kant, I. (1970 [1793]). 'On the Common Saying: This May be True in Theory, but it Does Not Apply in Practice' in Kant's Political Writings, edited by Hans Reiss, Cambridge: Cambridge University Press, 77; Reuben, R.C. (2004). 'Democracy and Dispute Resolution: The Problem of Arbitration.' Law and Contemporary Problems, 67(1/2), 279-320.

${ }_{61}$ Park, P. (2006). 'Knowledge and Participatory Research.' Handbook of Action Research, 2, 83-93.

62 Picanyol, E. (2015). 'Due Process and Soft Law in International Arbitration.' Spain Arbitration Review, 24, 29-62. 
debated. ${ }^{63}$ The goal of representativeness is to ensure that the main classes of interests, professions and international organisations are included. ${ }^{64}$ This book builds on and extends such insights to examine the turn towards decentralised representation in the global law-making process through such vehicles as UNCITRAL RCAP.

Advancing representation in the global law-making process remains central to the legitimacy of soft law. Alvarez describes how deficits in legitimacy and representation must be overcome at the vertical, horizontal and ideological levels. ${ }^{65}$ This project builds on his analysis by examining how engagement via a regional centre can strengthen legitimacy by expanding representation in the soft law formation process.

In conducting the first study of its kind exploring decentralised soft law-making through UNCITRAL RCAP, the book builds upon prior work, including comparative research on the development and design of mediation and arbitration institutions in both the Asia-Pacific region and worldwide. In particular, this book extends a multi-country study examining regional diversity and global harmonisation dynamics in arbitration and mediation practice in the Asia-Pacific region, ${ }^{66}$ as well as examination of the question of engagement in both the public ${ }^{67}$ and private law ${ }^{68}$ contexts.

\section{CONCLUSION}

In examining whether, and if so how, decentralised soft law-making at the regional level contributes to overcoming vertical and horizontal representational deficits in the global law-making process, this book finds that regional centres - in particular, the United Nations Commission on International Trade Law Regional Centre for Asia and the Pacific (UNCITRAL RCAP) - have

${ }_{63}$ Halliday, T.C., \& Carruthers, B.G. (2007). 'The Recursivity of Law: Global Norm Making and National Lawmaking in the Globalization of Corporate Insolvency Regimes.' American Journal of Sociology, 112(4), 1135-1202.

${ }_{64}$ Halliday, T.C., \& Carruthers, B.G. (2007). 'The Recursivity of Law: Global Norm Making and National Lawmaking in the Globalization of Corporate Insolvency Regimes.' American Journal of Sociology, 112(4), 1135-1202.

${ }_{65}$ Alvarez, J. (2007). 'Introducing the Themes [International Law and Democratic Theory].' Victoria University of Wellington Law Review, 38, 159-63.

${ }_{66}$ Ali, S. (2011). Resolving Disputes in the Asia-Pacific: International Mediation and Arbitration in East Asia and the West. Abingdon: Routledge.

${ }^{67}$ Ali, S. (2016). Governing Disasters: Engaging Local Populations in Humanitarian Relief. Cambridge: Cambridge University Press.

68 Ali, S. (2013). Consumer Financial Dispute Resolution in a Comparative Context: Principles, Systems and Practice. Cambridge: Cambridge University Press. 
contributed to decentralised engagement in the development and refinement of model laws in the realm of cross-border dispute resolution.

In both centralised and decentralised TLO systems, states continue to play a significant role in transnational law-making. However, the extent and depth of engagement varies. As TLOs become more decentralised, the depth and quality of access and engagement in law-making activities increases. The substantive findings of this book, alongside unique methodological contributions in the design of a new set of indicators tracking regional participation, provide useful insights supporting the expansion of regional centres in areas with historically limited representation in global law making including from within Africa, the Middle East and South America. 